\title{
APPLICATION OF THE MATHAR METHOD TO IDENTIFY INTERNAL STRESS VARIATION IN STEEL AS A WELDING PROCESS RESULT
}

\author{
Dariusz KOWALSKI ${ }^{1}$ \\ Gdansk University of Technology, Gdańsk, Poland
}

\begin{abstract}
The paper deals with the method to identify internal stresses in two-dimensional steel members. Steel members were investigated in the delivery stage and after assembly, by means of electric-arc welding. In order to perform the member assessment two methods to identify the stress variation were applied. The first is a non-destructive measurement method employing local external magnetic field and to detecting the induced voltage, including Barkhausen noise The analysis of the latter allows to assess internal stresses in a surface layer of the material. The second method, essential in the paper, is a semitrepanation Mathar method of tensometric strain variation measurement in the course of a controlled void-making in the material. Variation of internal stress distribution in the material led to the choice of welding technology to join. The assembly process altered the actual stresses and made up new stresses, triggering post-welding stresses as a response for the excessive stress variation.
\end{abstract}

Keywords: internal stresses, residual stresses, post-welding stresses, post-welding creep, Barkhausen effect, tensometric measurement, semi-trepanation Mathar method

${ }^{1}$ Corresponding author: Gdansk University of Technology, ul. Gabriela Narutowicza 11/12, 80-233 Gdańsk, Poland, e-mail: dariusz.kowalski@ wilis.pg.gda.pl, tel.: +48583472716 


\section{INTRODUCTION}

\subsection{Internal stresses in steel members}

The internal stresses in steel members are caused by thermal operations at various stages of material shaping and processing. It concerns both metallurgical processes of distinct steel products and the operations in steel manufacturing plants, where the products are adjusted to meet specific requirements of their final destination. Both processes of steel manufacturing and processing yield internal stresses not vanishing under a complete technological process (residual stresses), to possibly vary and accumulate. The internal stresses in steel are mainly produced by non-uniform heating and cooling, material phase changes under primary and secondary heating and cooling (cutting, welding, bending), plastic processes (rolling, bending), mechanical surface treatment (turning, grinding, milling, shot peening), thermal rectification of elements. Various contaminations and intrusions in the steel material, chemical composition, dislocation of crystalline lattice and material structure may trigger internal stresses in the material too. While internal stresses are determined decisions can be made upon repair of disabled elements, conditions of repair and the origin of element dysfunction and damage [1]-[3].

\subsection{Variations in internal stress distribution due to thermal processing}

In the course of welding the joined elements are subjected to high-temperature thermal processes in order to assemble the elements, meanwhile, changing the material structure. Electric arc - a locally concentrated heat source, moving along the welding groove, the location of a welded joint, generates non-uniform element heating. First of all the material is locally heated to its melting point, next, cooled to the external temperature. Steel is a common conductor, thus the vicinity of a weld is heated and cooled in a highly irregular pattern. Thermal assembly of steel members is accompanied by a physical thermal effect of expansion and shrinkage. Free thermal deflections are usually constrained by a surrounding structure, not subjected to thermal changes. The origin of stresses in a weld-joined material is one of the three:

a) moving local thermal field is a cause of a high temperature gradient, the highest temperature occurs close to the heat source, in the case of electric arc it exceeds $3000^{\circ} \mathrm{C}$. Non-uniform temperature distribution along a joint and the non-stationary heat flow trigger diverse thermal and mechanical material response,

b) external restraints, producing reaction forces to the thermal action in the welded material. The butt weld exhibits tensile stresses across the through weld to shrinkage of a melt material. The stress level is varying across the weld 
throat, also affected by plastic deformation of a surrounding material due to temperature,

c) structural variations in the domain of the temperature field due to welding. The weld is heated to its melting point, after an instant cooled to the external temperature. Both heating and cooling time intervals are very short. The time of phase changes in both original material and the weld is limited, so relevantly to the material sort hardening structures and hardening stresses may occur. The volumetric changes of a structural nature cause structural stresses after the range of critical temperatures is exceeded.

The distinct structural components of steel detects various specific volume, in an increasing order: austenite, pearlite, sorbite, bainite, martensite. The lowest specific volume refers to austenite, the highest to martensite. This the process of austenite change means the volume increase, the highest in the austenite martensite transition, lower while the output is pearlite or bainite. Structural volume changes, due to their rate and magnitude generate high stresses, exceeding the thermal expansion results, thus being the main cause of material strains and the possible hardening cracks.

The internal stresses in the welded material are affected by:

- the coolant applied after welding for a material, the faster being cooled in the martensite steel transition temperatures, the larger stresses occur,

- the starting temperature for cooling, higher temperature produces higher stresses,

- chemical composition - larger content of carbon and alloy admixtures increases internal stresses

- structure and quality of steel - the less homogeneous the higher stresses it causes,

- magnitude of an austenite grain, the greater grains in steel the higher stresses rise,

- shape and magnitude of a joint element - the greater and more developed, the more stress prone.

d) the variation of thermo-mechanical material parameters due to heating and cooling. Other parameters variable with temperature are:

- modulus of elasticity - Young's modulus E,

- Kirchhoff's modulus G,

- coefficient of thermal expansion,

- specific heat,

- heat conductivity.

The joint action of shrinkage of a solidifying weld metal and shrinkage to plastic strain of a surrounding material causes post-welding stresses. Shrinkage acts in every directions, the consequent strains are: 
- lateral strains, effects by element thickness, the type and dimensions of chamfering, welding method and technique

- longitudinal, affected by weld dimensions and the ratio: element crosssectional area vs. weld area

- oblique, caused by non-uniform material shrinkage. This kind of strain involves various deformations: bulging, distortion and warping, which deform selected profile parts or the entire element profiles.

The energy variations in metal processing and material phase changes cause internal stresses.

\subsection{Non-destructive methods to identify internal stresses}

In order to determine internal stresses in the considered case two methods were applied out of a great number of methods available in the field. The method incorporating Barkhausen noise effect [3], [4] is totally non-destructive. The paper [4] presents this method in the light of identification of stress distribution change for a welded steel element.

In order to verify internal stresses identified using this method, with the stress variation, additional experiments were conducted by means of a semi-trepanation method called Mathar or hole method. It is generally considered non-destructive, however, the measurement procedure involves drilling a low-diameter holes in the material. The holes may partially or entirely cross the element thickness. The stress identification method involves tensometric strain measurement due to a controlled loss (void) by means of a sequential hole drilling.

Tensometric rosettes are used herein, consisting of three tensometers of 0,45 and 90 deg. planar inclination angles, the hole location is situated between the tensometers. The hole in a steel element is made using a high-rotational turbine pneumatic drilling machine equipped with a special mill. The measurement covers material strains around a hole in the drilling course. Prior to drilling the native material shows internal stress equilibrium. The process of drilling, or voidmaking, the equilibrium is continuously updated. The variation of internal stress distribution due to drilling yields material strains in the hole vicinity, including the surface. The variations are recorded by a system of electric-resistance tensometers fastened to the steel element surface. While the mill drills the material the subsequent response may be registered too.

\section{DESCRIPTION OF THE CONDUCTED EXPERIMENT}

\subsection{Purpose of the study}

The experiment checks the ability to identify and compute internal stresses in steel structural elements due to welding. 


\subsection{The procedure}

The steel sheets were investigated to assess the internal stresses on the basis of the measured surface strain. Two test pieces were rejected from the same sheet, in order to achieve equal input data: chemical composition, mechanical and thermal processing on the material, the squeezing stress level, surface conditions due to flatness, clearness, roughness, possible corrosion stage at the surface, development of a surface layer - mill scale.

The essential feature was the absence of loading history or any surface treatment of the tested elements. The dimensions of every sheet were $215 \times 478 \mathrm{~mm}$, the mean thickness was $4.77 \mathrm{~mm}$. The structural steel of a yield limit equal $335 \mathrm{MPa}$ was rolled thermomechanically in the manufacturing course. Prior to the experiment both surfaces were treated manually, not to cause any changes in surface and sub-surface internal stresses due to cleaning. The assessment of internal stresses included two steps. The first was conducted in the delivery phase, to determine internal stresses to metallurgical manufacturing process. This is a reference for the measurements of the second step.

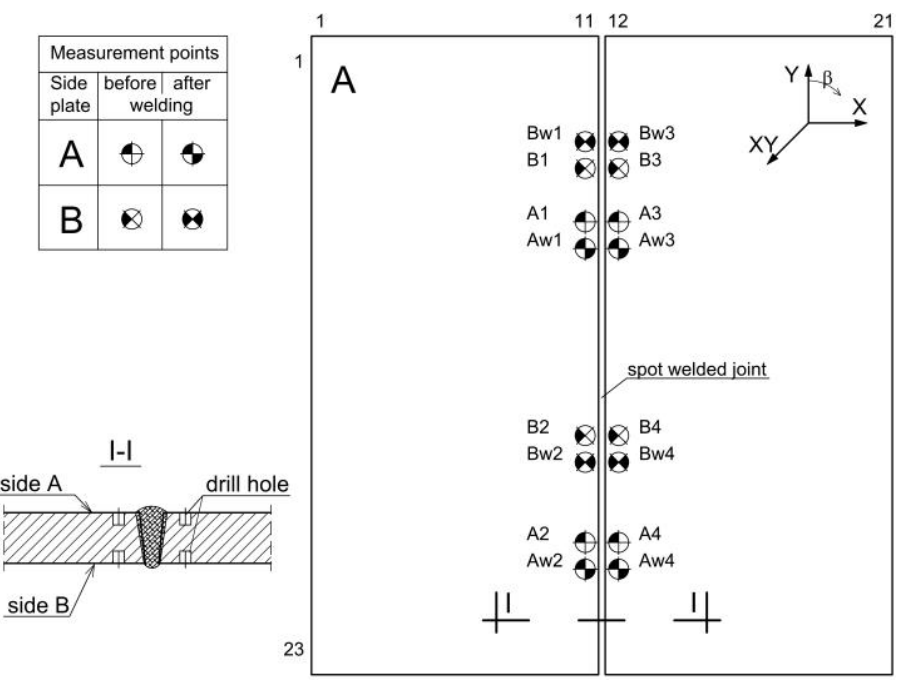

Fig. 1. Geometry of the investigated element

The measurements were repeated for the same elements welded along the greater sheet side. A single-sided V-type butt weld was done, the welding was made under cover of inactive protective gas. The connection was made without any internal or external stiffeners, no precautions limiting the post-welding element shape were implemented too. In each state of stress identification four experimental holes were drilled on every side of the element. The holes were situated close to the sheet surface intended for the connection (fig.1), considering geometric conditions to locate tensometric rosettes after welding. 
The deformed geometry due to thermal action in the welding course was presented in detail in the paper [4]. The deformation mode in the considered element was corresponding to the welding seam. Oblique strains occurred here, typical for the non-symmetric butt weld. Flatness deformation of sheets occurred here, due to a single-sided welding pattern. The measurement conditions for the internal stresses were presented in fig. 2 .

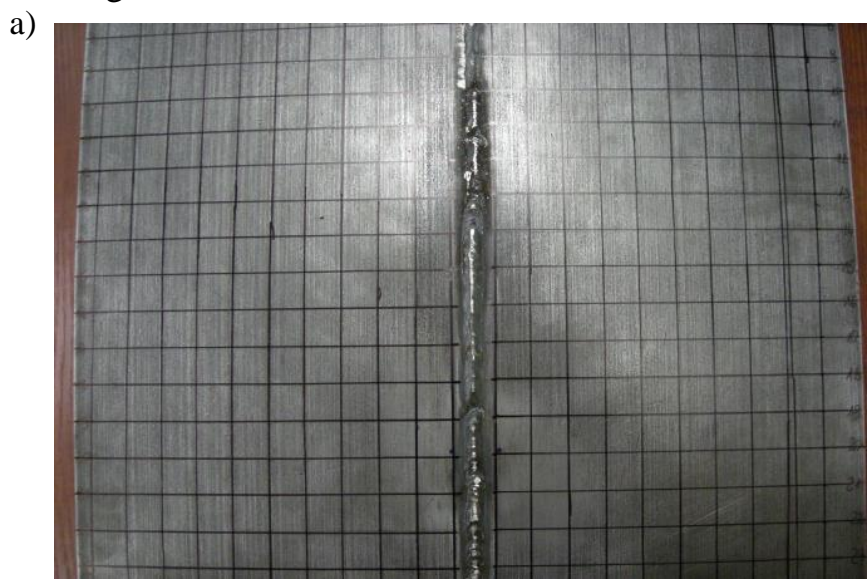

b)

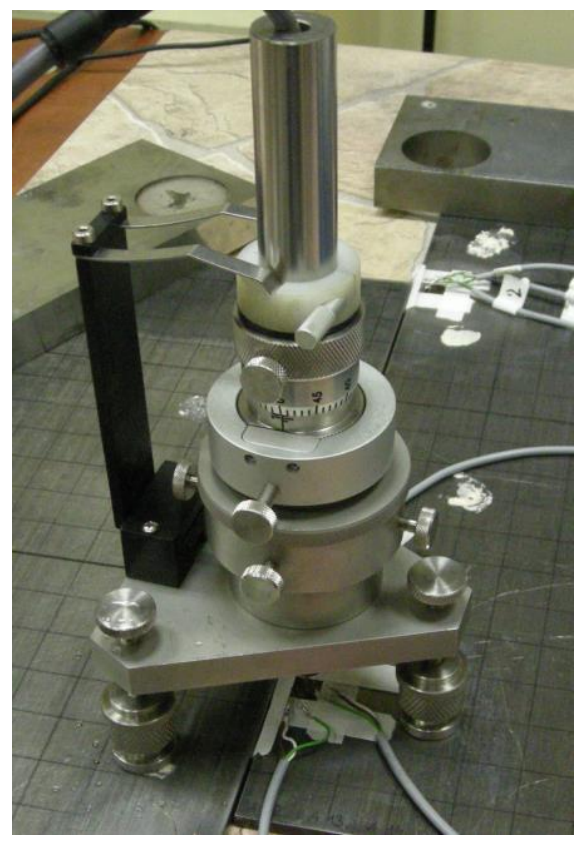

c)

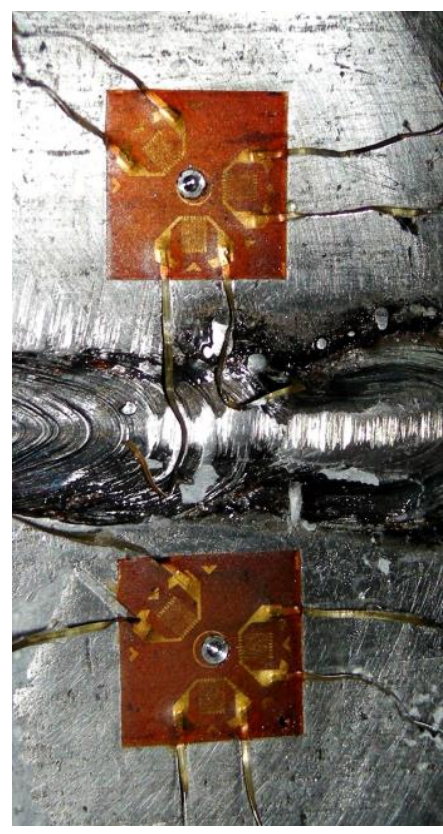

Fig. 2. The conditions and procedure of the Mathar method measurements welded sheets, b) the drilling setup, c) tensometric rosettes after drilling 
Figers 3 and 4 present strains at the surface of a steel element due to material loss (void), an information on internal stresses at specified experimental stages.
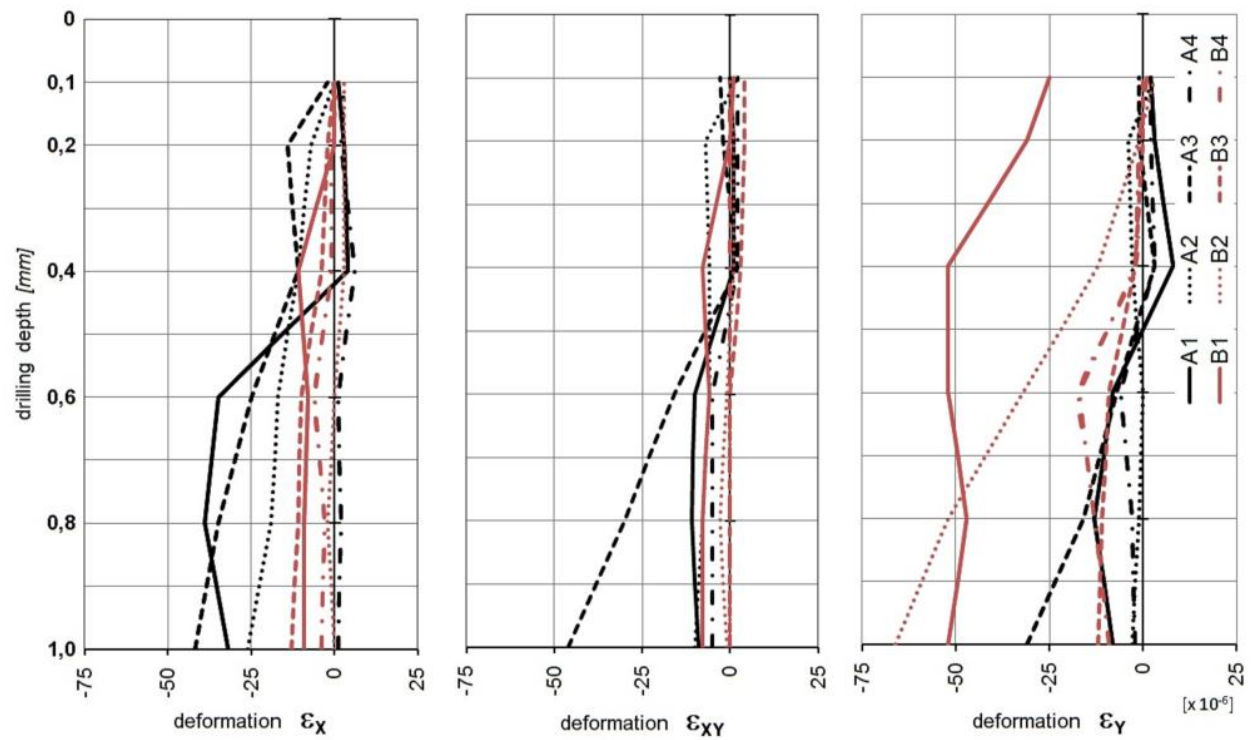

Fig. 3. Strains registered in the experiment at the delivery phase
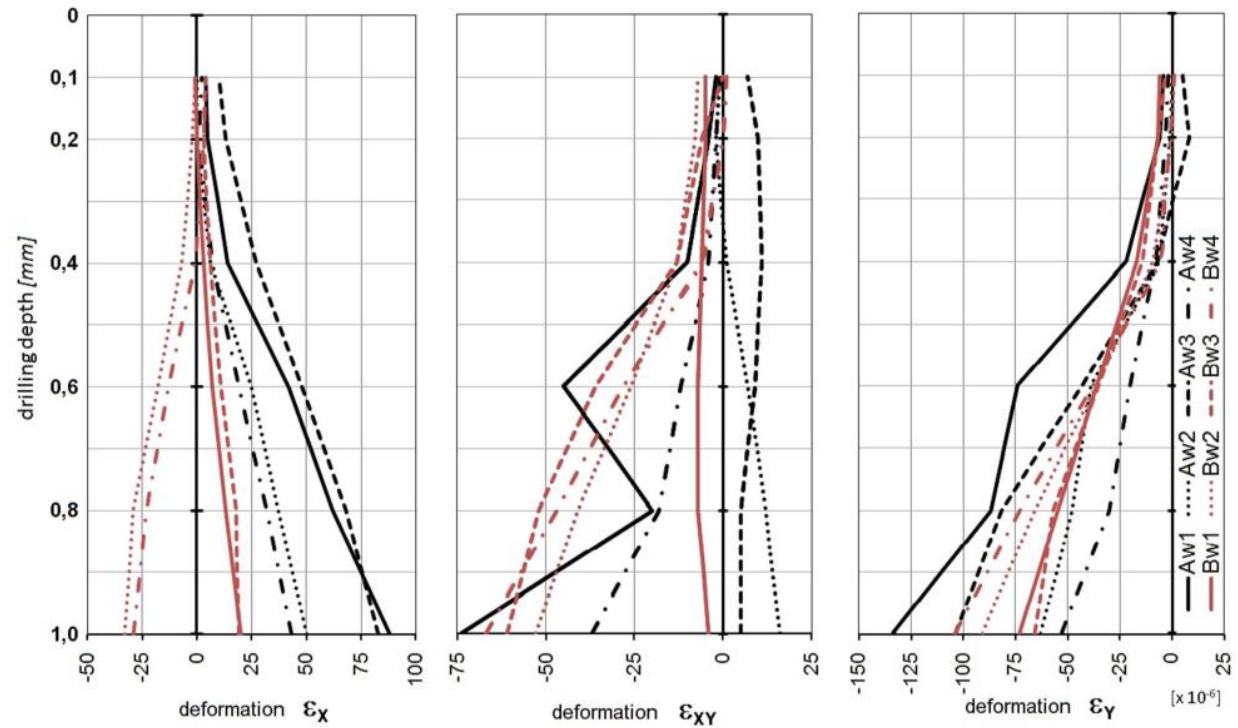

Fig. 4. Strains registered in the experiment, post-welding phase 
The final registered strains are presented in fig. 5.
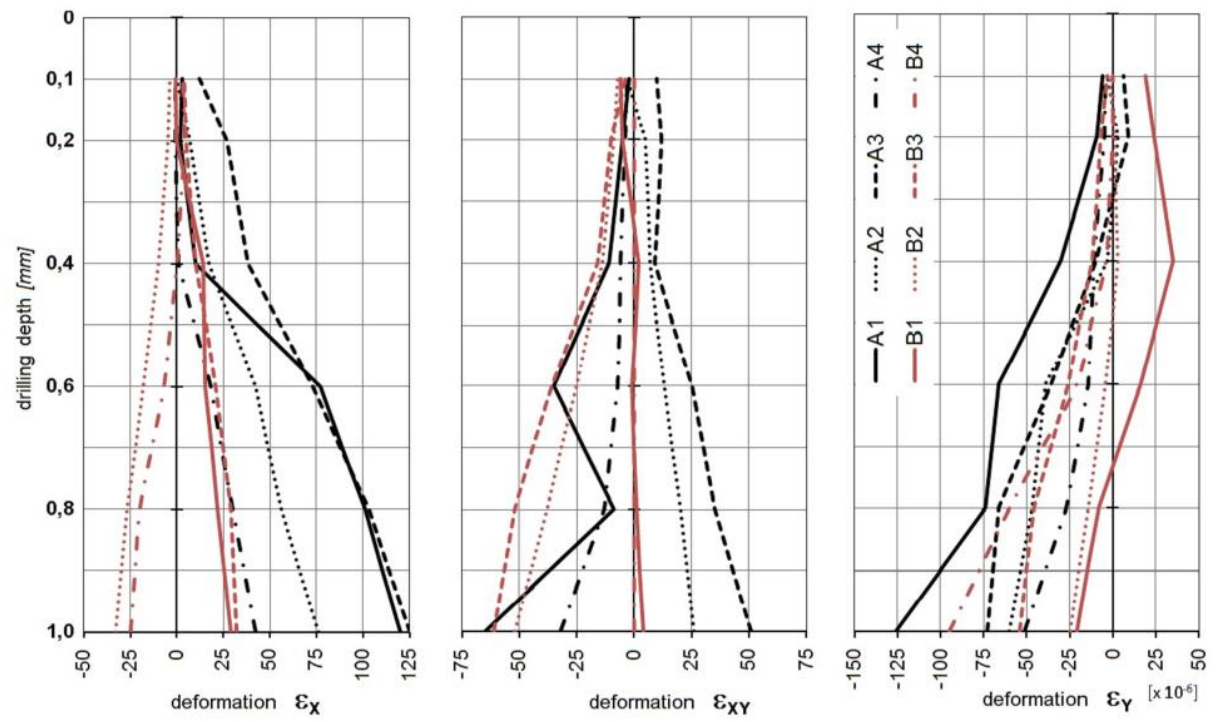

Fig. 5. The strain increments due to welding

The strain distribution measured in selected points on a material surface are presented in fig. 6 .
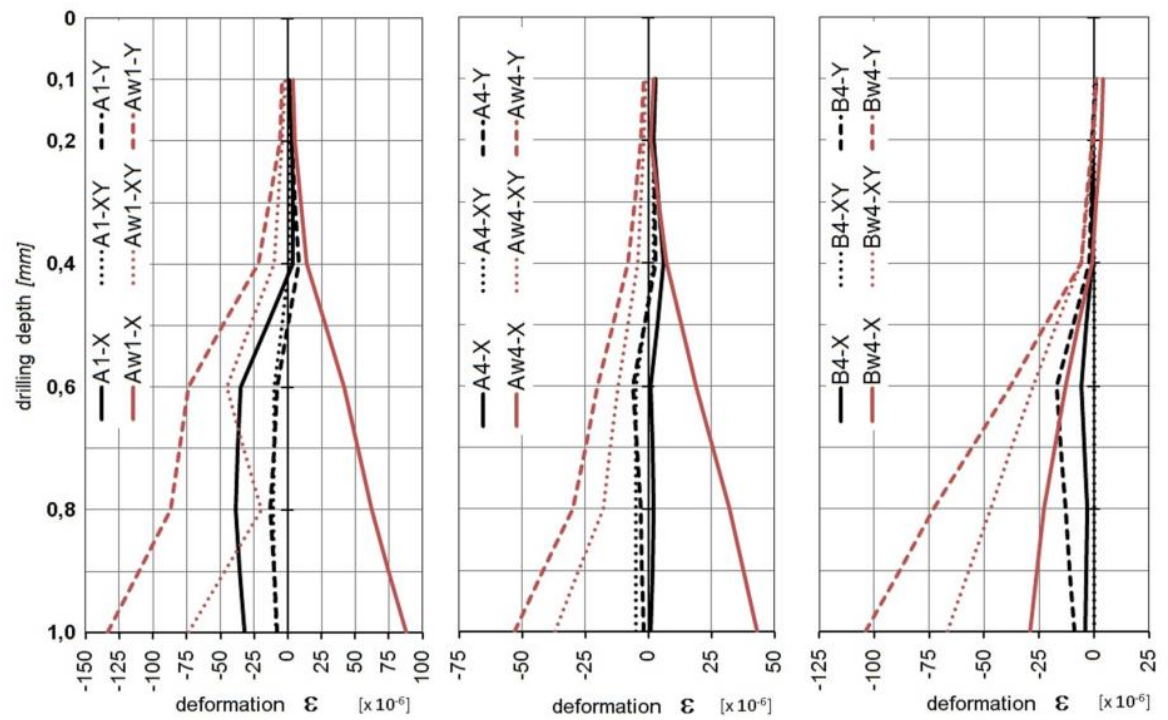

Fig. 6. The strain variation in two stages for a selected point 


\section{ANALYSIS OF RESULTS}

Carried out invasive tests with the use of semi-trepanation Mathar method allow for identification of the conditions which influence stresses variation in the material under external thermal factors applied during welding process. Presented in the fig. 3 strains measured in the delivery phase show a little increase of the registered strain values. However their shapes indicate variation of the stress distribution in that phase. We can take the assumption, that generally registered strains are within the limits of 10 units of strain. Re-examination after welding (fig.4) shows a significant change of the stress distribution to the depth of the drilled hole. Measured strain increases reach values of $12510^{-6}$ (fig. 5). The behaviour of strains in two measuring points are presented in fig. 6. Measured material strains allow for identification of the values of internal stresses in investigated steel members. Calculation rules contained in the standard [5] and implemented to commercial computer programme [6] allow to achieve that aim. Calculation results for chosen measuring points are presented in the table 1.

Table 1. Examples of the stress value variations in a surface layer

\begin{tabular}{|l|c|c|c|}
\hline \multirow{2}{*}{$\begin{array}{c}\text { Measuring } \\
\text { point }\end{array}$} & $\boldsymbol{\sigma}_{\mathbf{X}}$ & $\boldsymbol{\sigma}_{\mathbf{Y}}$ & $\boldsymbol{\tau}_{\mathbf{X Y}}$ \\
\cline { 2 - 4 } & \multicolumn{3}{|c|}{$[\mathrm{MPa}]$} \\
\hline $\mathrm{A} 1$ & -13 & -9 & -7 \\
\hline $\mathrm{Aw} 1$ & 13 & -13 & -10 \\
\hline$\Delta \boldsymbol{\sigma} / \tau$ & $\mathbf{2 6}$ & $\mathbf{- 4}$ & $\mathbf{- 3}$ \\
\hline $\mathrm{A} 3$ & 39 & 13 & 8 \\
\hline $\mathrm{A} w 3$ & -52 & -45 & -3 \\
\hline$\Delta \boldsymbol{\sigma} / \tau$ & $\mathbf{- 9 1}$ & $\mathbf{- 5 8}$ & $\mathbf{- 1 1}$ \\
\hline $\mathrm{B} 1$ & -14 & -1 & 9 \\
\hline $\mathrm{B} w 1$ & 25 & 11 & -9 \\
\hline$\Delta \boldsymbol{\sigma} / \boldsymbol{\tau}$ & $\mathbf{3 9}$ & $\mathbf{1 2}$ & $\mathbf{- 1 8}$ \\
\hline $\mathrm{B} 3$ & 1 & 0 & 17 \\
\hline $\mathrm{B} w 3$ & -10 & 17 & -7 \\
\hline$\Delta \boldsymbol{\sigma} / \tau$ & $\mathbf{- 1 1}$ & $\mathbf{- 1 7}$ & $\mathbf{- 2 4}$ \\
\hline
\end{tabular}

\begin{tabular}{|c|c|c|c|}
\hline$\sigma_{\max }$ & $\sigma_{\min }$ & $\tau_{\max }$ & $\beta$ \\
\hline \multicolumn{3}{|c|}{$[\mathrm{MPa}]$} & {$\left[^{\circ}\right]$} \\
\hline-4 & -18 & 7 & 52 \\
\hline 16 & -17 & 16 & 16 \\
\hline \multicolumn{4}{|c|}{} \\
\hline 41 & 11 & 15 & -74 \\
\hline-44 & -53 & 4 & 18 \\
\hline \multicolumn{4}{|}{} \\
\hline 3 & -18 & 11 & -64 \\
\hline 30 & 6 & 12 & 26 \\
\hline \multicolumn{4}{|c|}{} \\
\hline 17 & -16 & 17 & 45 \\
\hline 18 & -12 & 15 & 13 \\
\hline & & \\
\hline
\end{tabular}


Exemplary distributions of stresses on the depth of the hole shown in fig. 7.
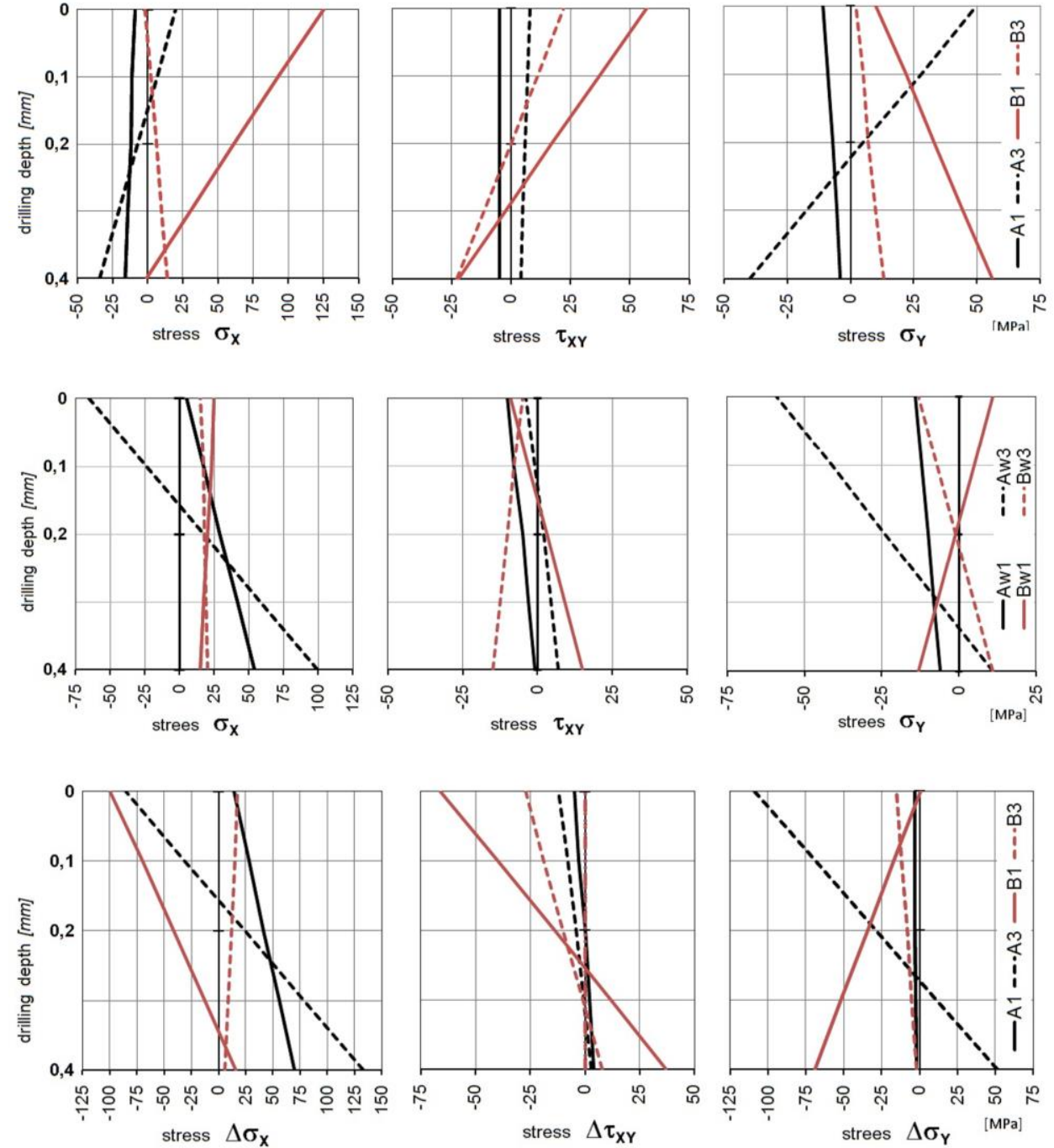

Fig. 7. Exemplary distributions of stresses at depth in selected points

\section{CONCLUSIONS}

Conducted research confirms expected variation of internal stress distribution and allows for identification of the stresses values in the examined points. Anyway, due to discrete nature of the measuring method, it does not give us global information on the material behaviour. Part of the introduced thermal energy is 
absorbed by material and produces welding deformation. Those deformations causes reduction of the internal stress values. The measured values of material stresses present the post-welding stress state. Applying of the members rectification causes farther changes of the internal stress values.

The presented method gives discrete results due to spot measurements, what is a kind of the method drawback. What is more it is a destructive method: the values of internal stresses can be measured only once at the same point. Further tests have to be carried out at the adjacent place what, in some cases, can induce quite big errors. Moreover the method does not enable exact stress identification when stress distribution is various through material thickness. Results provided by calculation rules of the method have about $10 \%$ error.

Studies carried out on this method have to verify Barkhausen noise method and check the possibility of the internal stresses identification in shell elements with geometrical imperfections caused by both: welding processes and external impacts [7], [8], [9], [10] such as objects uneven settlement and elements prestressing during structures assembling.

\section{REFERENCES}

1. Senczyk D., Moryksiewicz S.: Residual stresses - concepts and classifications, Non-destructive Testing - Internet Service, 2007.

2. Paczkowska T., Paczkowski W., Wróblewski T.: The influence of ground settlement on the condition of skeleton steel structure, 23th Conference of Structural Failures, Szczecin-Międzyzdroje, May 23-26, 2007, 639-646.

3. Dyląg Z., Orłoś Z.: Analysis of the possibility of semi-multiphase trepanation in the case of uniaxial stress, Engineering Transactions 4/1960, 845-869.

4. Kowalski D.: Application of Barkhausen effect in the impact assessment of welding to internal stress distribution in steel, Metal Structures 2016. Proceedings of the XIII International Conference on Metal Structures (ICMS2016, Zielona Góra, Poland, 15-17 June 2016), London: CRC Press, 2016, 353-359.

5. Łukowicz A., Kowalski D.: Application of Barkhausen method to determine internal stresses in cold-rolled and hot-rolled sheets, Metal Structures 2016. Proceedings of the XIII International Conference on Metal Structures (ICMS2016, Zielona Góra, Poland, 15-17 June 2016), London, CRC Press, 2016, 345-351.

6. ASTM 837-08 Standard test method for determining residual stresses by the hole-drilling strain-gate method.

7. Kowalski D.: Stesses in tank shell with shape deformation, International Conference Design, Inspection, Maitenance and Operation of Cylindrical 
Steel Tanks and Pipelines. Prague - Kralupy nad Vltavou, Czech Republic, 811 October 2003, Ed. V. Krupka, 2003, 143-147.

8. Kowalski D.: Influence of initial imperfections on the vertical tank side stresses, Gdańsk University of Technology, 2004.

9. Kowalski D.: Wpływ imperfekcji wykonawczych na stan naprężeń w płaszczu stalowego zbiornika o osi pionowej, Gdańsk University of Technology, 2004.

10. Kowalski D.: Influence of geometrical imperfections on stresses in cylindrical shells, Shell Structures: Theory and Applications (10th SSTA), October 1618, 2013, Gdańsk (Poland), 2013, 527-530.

\section{WYKORZYSTANIE METODY MATHARA DO IDENTYFIKACJI ZMIAN NAPRĘŻEŃ WEWNĘTRZNYCH W MATERIALE STALOWYM PO PROCESIE SPAWANIA}

\section{Streszczenie}

W artykule przedstawiono zastosowanie metod identyfikacji stanu naprężeń wewnętrznych występujących w płaskich materiałach stalowych. Materiał stalowy blachy badany był w stanie dostawy oraz po procesie jego łączenia za pomocą elektrycznego spawania łukowego. Do oceny stanu naprężeń wewnętrznych w badanych elementach wykorzystano dwie metody identyfikacji zamiany tego stanu. Pierwszą, była nieniszcząca metoda badawcza oparta na pomiarach z wykorzystaniem lokalnego, zewnętrznego pola magnetycznego i pomiarze wyindukowanego napięcia, które zawiera szum Barkhausena. Na podstawie jego analizy można określić stan naprężeń wewnętrznych materiału jaki występuje w jego przypowierzchniowej warstwie. Drugą była opisana w niniejszym artykule, metoda półtrepanacyjna Mathara, polegająca na tensometrycznym pomiarze zmiany odkształceń badanego materiału w trakcie powstawania kontrolowanego ubytku materiału w postaci wierconego otworu nieprzelotowego. Fakt zmiany rozkładu naprężeń wewnętrznych $\mathrm{w}$ badanym materiale wynikał zastosowanego sposobu połączenia elementów poprzez spawanie. Proces łączenia elementów płaskich spowodował powstanie nowego oraz zmianę istniejącego rozkładu naprężeń wewnętrznych. Proces spawalniczy wygenerował również odkształcenia pospawalnicze w łączonych elementach, które są odpowiedzią na nadmierną ich zmianę naprężeń wewnętrznych.

Słowa kluczowe: naprężenia własne, naprężenia pozostające, naprężenia pospawalnicze, skurcz spawalniczy, efekt Barkhausena, pomiar tensometryczny, metoda półtrepanacyjna Mathara.

Editor received the manuscript: 14.07.2016 